Tér és Társadalom 19. évf. 2005/1. 115-139. p.

Tér és Társadalom

XIX. évf. 2005

1: $115-161$

\title{
KITEKINTÓ
}

\section{KISTÉRSÉGEK, CIVILEK, SZERKEZETEK}

\author{
(Micro Regions, Civils, Structures) \\ BODÓ BARNA
}

"Minden embernek tartozom,
és minden ember tartozik nekem."
Németh László

Kulcsszavak:

kistérség civil szféra alapszï̌kségletek érdekvédelem innovációspotenciál stratégia civil integráció

A kistérség olyan természetes körzet, amelynek létét a kïlönbözö kapcsolati hálók mutatják meg. Napjainkban egyre komolyabbá váló kérdés: mivé lesz a nemzeti centrum, és milyen jelentöségre tesznek/tehetnek szert a félperifériaként müködö kis és nagyobb tajak". Milyen identitásfolyamatok indulnak el és erösödnek fel, illetve ezek miként strukturáljâk â a politikai érdekérvényesítés cél-és kategória-rendszerét?

Bizonyosnak tünik: a (kis)régió aspirációs keretként kutatási szemléletmódokba is bekeriil. Ezért tarthat kutatói érdeklödésre számot a (kis)térségi önépítkezés, folyanata, illetve annak esetleges elmaradása.

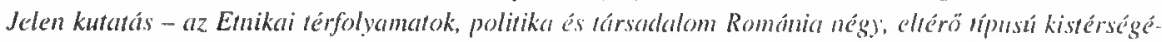
ben címü, átfogó kutatâs részeként - célja a kistérségi civil világ innovíciós potenciáljának, létének és mibenlétének a vizsgálata.

\section{Térszerkezet és civil szerepvállalás}

Térszerkezet.

Tessék ízlelni a fogalmat. Lóduljon meg a képzelet. Induljon el az elemzés malma.

Tér. Mennyi mindent jelöl. A polgárnak otthont vagy a lehetöségét. A közgazdásznak helyi potenciált. A költőnek szárnyalást. A politikusnak beágyazottságot...

Szerkezet. Mérnöki fogalom, összerakottság, megcsináltság. Gép. Gépi.

Térszerkezet. Itt a tér területet jelent. A szerkezet pedig társadalmi struktúrákat. A kettő együtt: természeti értékek és térségi terhelhetőség; területhasználat és térségi egységek; infrastruktúra és új funkciók; hagyomány és fejlesztés; értékek és érdekek.

Ha térszerkezetről szól a szakember, összefüggó strukturált rendszerre gondol, fejlesztési potenciált számol, le- és kimaradástól óv. Atomi a mainak mondott társadalom: csak mozgásban, a mozgás által van.

A szakember térségi feladatoknak megfelelő területhasználatról beszél, a térszerkezethez mindenféle program kapcsolódik, éspedig: a településrendszer fejlesztése, a térszerkezet fejlesztése, tájrendezés (természet- és tájvédelem), kulturális örökség 
védelme, gazdaságfejlesztés és területrendezés, üdülés és idegenforgalom fejlesztése, terïlet-felhasználási program, közlekedési program, energiagazdálkodási program, hírközlési program, vízgazdálkodási program, kömyezetvédelem. És még folytathatnánk.

És mindezen programok egy valamely kistérségben. Ha van ilyen. Amennyiben elismerik, hogy van ilyen. Amennyiben ott, ahol akarják, hogy legyen ilyen.

A kistérség - helyi kapcsolat. Az a keret, amely összefog, identitást ad. Ahol (még?) működnek a természetes emberi reflexek. A kistérség nem falu, amely ritka kivétellel eröforrás-szegény, csak emberi kapcsolatokból vannak fölös tartalékai. Nem (nagy)város, ahol az egyén sokszor képtelen olyan kapcsolatháló kialakitására, hogy az együttmüködés szükségességének a felismerését a valahova tartozás érzése segítse gyakorlati programban tárgyiasulni. És végképp nem megye, olyan területi egység, amelyet a központi hatalom közigazgatási kényszerek és szándékok mentén alakít ki, s igen ritkán találkozhat - Délkelet-Európában legalábbis - az alulról strukturálódó, terület-centrikus identitásképletekkel. Ha a magyar közigazgatás nyelvi innovációit kívánjuk használni, akkor járást mondunk, akkora területet, amekkorát emberfia napi barangolással bejárhatott akkoron, amikor nem a motorok adták a világ lényegét.

A kistérség tehát természetes körzet, a mindennapi mozgások eredménye, de azt is mondhatjuk, hogy létét a különbözö kápcsolati hálók mutatják meg, ugyanis nem külön szándék alakítja ki - létrejön az együttmüködési formák és a valamilyen alakban mindig megmutatkozó szolidaritások mentén. Tagolják azt a teret, amely az egyformaság és személytelenség végtelenségében embertelen, tehát elfogadhatatlan.

Ha a kistérség ennyire emberi, velünk és általunk való, akkor csodálkozzunk, hogy a legutóbbi időkig a kistérség volt a térrel kapcsolatos kérdésfelvetések és vizsgálatok Hamupipökéje. Bár a demokrácia belsö logikájából adódik a kistérségek kiemelt figyelemben való részesítése, vegyük észre a helyzet kettősségét: az identitást tagoló és hordozó alapstruktúra jelentőségét elmossák olyan elemek, amelyeket a közigazgatás kényszerei alakítanak ki.

$\mathrm{Az}$ átrendeződési folyamatok összességében - fontos és jelentös - munkákat szentelnek a regionalizmus különbözö szintủ elemeinek, mégis a kistérségek többnyire a felsorolásokban jelennek meg, mint a sokféle térváltozat - külön nem taglalt - egyike.'

Létezik egy visszásság, egy paradoxon a kistérségeket illetően, és oka, intézmények és politikák szintjén azonosítható oka kell, hogy legyen annak, ha az indokolt figyelem valamilyen vonatkozásban várat magára. A ,nincs, de kellene”-helyzet alapdilemmája: mivé lesz a nemzeti centrum, és milyen jelentöségre tesznek/tehetnek szert a félperifériaként müködő kis és nagyobb tájak? Milyen identitásfolyamatok indulnak el és erösödnek fel, illetve ezek miként strukturálják át a politikai érdekérvényesítés cél- és kategória-rendszerét? Olyan kérdések, amelyek iránt fokozódó az érdeklödés nemzeti és nemzetközi szinten egyaránt.

Annyi bizonyosnak tủnik: elkerülhetetlen, hogy a (kis)régió, mint közös (európai) aspirációink kerete kutatási szemléletmódokba is bekerüljön. A fejlesztési stratégiákat illetően a kisrégió külön figyelmet azért érdemel, mert a kistérségek szintjén meg- 
lévő közösségi szolidaritás jelentős mozgatóerö. Ezért tarthat kutatói érdeklödésre számot a (kis)térségi önépítkezés folyamata, illetve annak esetleges elmaradása.

És ekként kerül a civil szféra arra a bizonyos térszerkezeti asztalra.

A térstruktúrák alakulása a politikai nagy- és kisléptékú mozgásain túl a civil szféra, a helyi társadalom erővonalainak, öntételezö folyamatainak is függvénye. Ehhez pedig tisztázni kellene, mit értünk önépítkező civil társadalmon.

Ha bonyolítani kívánjuk a képletet, illetve figyelembe vesszük a helyi identitás etnikai dimenzióját, akkor az önépítkezö helyett, illetve mellé beillesztendő volna egy újabb jelzö: önépítkezỏ magyar civil társadalom. Mivel pedig a romániai magyar társadalom fogalmát is jobbára csak körülhatárolni sikerült, s nem egyértelmúen meghatározni (Túros 1995), a romániai magyar civil társadalom egyszerủen és egyszerüsítően jelenti a létező intézményhálózatot, illetve magát a mozgalmat, az építkezö folyamatot. Erre a kettösségre különben Arató András (1999) hívja fel a figyelmet, hiszen a közép-kelet-európai átmenet folyamataiban a civil társadalom egyszerre jelentette az autoritárius hatalmi rendszer tagadását és ugyanakkor az érdektagolás szervezeti feltételeinek a megteremtésére való törekvést. Persze, az idők során szinte nem volt olyan közösségi feladat/cél, amelynek okán a civil társadalom, mint keret és eszköz szóba nem került volna, hiszen minden, ami a „félelem falának" a bomlását segítette, ilyen vagy olyan módon civil.

A civil szerveződések alakulási folyamata nem más, mint egy általános feleszmélés strukturális tárgyiasulása és mozgalommá állandósulása. A folyamatnak megvannak a hely- és időfüggő sajátosságai, s ebben meghatározó, hogy az elitek milyen hagyomány-értelmezéseket jelenítenek meg, illetve miként viszonyulnak a társadalomfejlódés alapvető kérdéseihez. Ugyanakkor maga a folyamat nem választható el a civil társadalomról és a civil szféra helyzetéről szóló, időben a jelzett tényezök függvényében hangsúly-eltolódásokat mutató diskurzustól. Helyesen állapítja meg Papp Z. Attila (2001), hogy bármiként is bövül(t) a civil társadalom fogalmának értelmezése az idők folyamán, létjogosultsága feltételezi a köz- és magánszféra dichotóm szétválasztását. Figyelemmel kell lenni a továbbiakban a globális civilitás megjelenésére (Szabó 1999), és természetesen jelentkezik a romániai nyil vánosságban zajló idevágó diskurzus hatása is. ${ }^{2}$

Konszenzus mutatkozik abban, hogy a civil társadalmat önmagában az életképes, jövöorientáltan cselekvő helyi közösségek kialakulását elösegítő keretfeltételnek kell tekinteni, sok esetben mégis a civil társadalom léte elsösorban a politika ellenörzöttségét jelenti, egy olyan közösségi teret, amelyben a közösségi szolidaritás szükségességét nem tagadva léteznek olyan struktúrák, amelyek képesek a szakpolitikai szerepkörön túlmutató, a harmadik szektor önállóságát igazoló korrekciós jelzések leadására.

Gondoljuk tovább az idézett paradoxont. A demokratikus átmenet folyamataiban általában, ekként Közép-Kelet-Európában is komoly szerepet játszott-játszik az önmagát a hatalommal szemben megfogalmazó civil társadalom, éppen mivel képes a hatalom által ellenörzött kommunikációtól független nyilvánosság létrehozására. Ez a civil társadalom alulról induló - tehát nem kormányzati - kezdeményezéseket 
és felelős személyek társulási szabadságát és képességét feltételezi, ugyanakkor többnyire a létezỏ kritikáját jelenti, bizonyos (erő)fölénynek a tagadását. Ezt a helyzetet bonyolítja tovább a civil társadalommal kapcsolatos, több román szerzö által hivatkozott paradoxon: a civil társadalom szükséges és reményt keltő, de romániai megvalósítása puszta illúzió (Papp 2001, 117).

A civil társadalom nyugati minta szerinti, térben és időben különböző helyszínek és közösségek vonatkozásában történő megvalósíthatósága dilemmaként nem egyszer felmerül (Chatterjee 2001), természetes módon, hiszen a civil társadalom által képviselt morális tartalom kulturálisan kondicionált. A civil társadalom normativitása egyféleképpen nyilvánul meg a nyugati, másként az ettöl eltérö társadalmikulturális közegben. A nyugati minta szerinti modern egyesületi élet olyan szerveződéseket jelent, amelyek alapja a tagok egyenlösége, autonómiája, be- és kilépési szabadsága, illetve a döntéshozatal procedurális szabályozottsága. Bár e feltételeket sokszor és sok helyen csak részben teljesítik, az egyesületi élet modernizációs hatása vitathatatlan. Ezért mondható, hogy a civil szféra lényege a felelös egyének társulása azért, hogy - a demokrácia jeles teoretikusa, Dahrendorf szerint - a mindenkori hatalmi rendszer ,felelötlenségével” szemben megfelelö módon felléphessenek. A civil társadalom - nem azonos a civil szférával - a jogok tényleges intézményesülését mozdítja elö, mindenek elött Kelet-Európában, ahol a nyilvánosság kontroll szerepe figyelmeztet egy másik jeles gondolkodó, Arató András - igencsak korlátozott mértékben teljesül mindmáig.

Függetlenül attól, hogy milyen elméleti háttérrel illetve gyakorlati szándékkal jött/hozatott létre, a legtöbb erdélyi magyar civil szerveződés képviselöje vallja, hogy a civil társadalom újfajta érzékenységre épít a helyi, a sajátos és a véletlenszerủ vonatkozásában, és olyan polgárokat feltételez, akik részt kívánnak vállalni a köz ügyeinek intézésében.

A civil eszmény jegyében, állítja Seligman a civil társadalom eszméjéröl írott könyvében (1997), az emberek beláthatóvá kívánják tenni a közéletet, különböző szervezödések kialakításával azt az igényüket jelzik, hogy a döntések helyileg és nem valamilyen ködbe vesző távoli államgépezet révén szülessenek meg. A civil eszmény feltételezi a hatalmi pólustól független kollektív entitás létét, és itt a hangsúly a közösségi mivoltra helyezendö. Az államtól független, felelös közösségi megnyilatkozás a pluralizmus egyik eleme, s ilyenként nem csupán politikai, de etikai szempontból is lényeges. Ebben a helyzetben másodlagos, ki és miért indítja kezdeményezését, lényeges viszont, hogy a közösségi kontroll éppen a civil szféra keretfeltételeit illetően kialakuljon és hasson.

\section{Kistérségi civilek kutatása}

Jelen kutatás - az Etnikai térfolyamatok, politika és társadalom Románia négy eltérö típusú kistérségében átfogó kutatás részeként - célja nem térszerkezeteknek, települések rendszerének, funkcióknak és szerepköröknek a vizsgálata, s még kevésbé táji-természeti elemek hálózatának és ezek változásainak a feltárása. Amikor 
a kistérségi civil világ vizsgálatára vállalkozunk, akkor bizonyos innovációs potenciált keresünk, ennek létét és mibenlétét kutatjuk.

Civil szervezetekröl szólva tudatában vagyunk annak, hogy milyen szerep, illetve funkció társul ezekhez helyi, illetve országos szinten, de nem célunk ezek megnyilvánulási formáinak a vizsgálata, különösen nem azon helyi társadalmak esetében, ahol az intézményi kapcsolatoknál fontosabbak az emberi kapcsolatok, ahol a helyi nyilvánosság elsődleges tényezője a személytelenséget biztosító sajtó helyett a közvetlen kapcsolatok rendszere. Azt sem kérdeztük meg senkitöl, semmilyen formában, miként ítéli meg a helyi közösség innovációs potenciálját, pedig a civil szerepvállalás éppen arról szól, hogy miként vállalnak át valakik olyan feladatokat, amelyeket valamilyen intézmény nem vagy nem megfeleló módon teljesít. A civil világ kulcsszavait - értékmegörzés és funkciófejlesztés - bele kell érteni, mert benne van mindabban, amit a kutatás során megszólaltatottak elmondanak.

A kutatás keretében azt vizsgáltuk, milyen helyi szerveződések (alapítvány, egyesület, társaság, klub, szövetség) jöttek létre a négy kistérségben, milyen területen (érdekvédelem, kultúra, oktatás, hagyományörzés, egyházi, média, szociálissegélynyújtás, gazdasági, tudományos-szakmai, sport-szabadidón ${ }^{3}$ tevékenykednek, kik és milyen körülmények között hozták ezeket létre, miként biztosítják a müködés anyagi feltételeit, illetve megvannak-e a civil integráció (együttmúködés, közös fellépés, stratégia) feltételei. Explicit hipotézist nem fogalmaztunk meg, mert országos szinten sem létezik a civil szférát illetően olyan program (hogy ne mondjunk stratégiát), amely világosan tételezi a civil szerepböl következö felelösséget, és ami meghatározó! - a szerepkör betöltésének intézményi-anyagi feltételeit, vagyis azt a keretet, amely a politikai és civil szféra elvi szinten taglalt és társadalmilag pozitív partneri viszonyát lehetővé teszi. A kutatás feltáro, információt szolgáltat a partneri viszony kialakítását kondicionáló feltételekröl, azokról a mentális, szervezeti és anyagi folyamatokról, amelyek a civil világot (e négy térségben) jellemzik.

A végső következtetésekböl annyit érdemes elöre bocsátani, amennyi szükséges ahhoz, hogy „beállítsa” az elemzéssel kapcsolatos elvárások szintjét: a vizsgált civil szervezetek többsége alapszükségletek kielégítését tekinti feladatának, $s$ alig van példa arra, hogy távlatos, a létezőhöz képest javulást, többet, fejlődést jelentő programokat vállalnának. ${ }^{4}$

A terepkutatás strukturált interjúk készítését jelentette a négy kistérség (Gyímesek, Székelykeresztúr és térsége, Kalotaszeg, Pécska és térsége) civil szervezeteinek a vezetöivel, helyi véleményvezérekkel, politikai és/illetve önkormányzati vezetỏivel. Azt szerettük volna, hogy minden térségben kikérjük az egyesületi élettel kapcsolatosan a civil szervezetek vezetôi mellett a helyi elit - polgármester, RMDSZ-elnök, orvos, pap, iskolaigazgató - véleményét. Objektív és szubjektív okok egyaránt közrejátszottak abban, hogy a terv csak részben valósult meg: sem a teljes civil szervezeti struktúra képviselete, sem pedig a teljes helyi elit nem került megszólaltatásra. Véleményünk szerint ez a kutatás eredményét kevéssé befolyásolja, ugyanis a viszonylag kis szervezet-szám okán kvantitatív elemzést akkor sem végezhettünk volna, ha a civil szerveződéseket illetöen pontos és mindenre kiterjedö 
adatok birtokába kerülünk. A véleményvezérek, a helyi elit teljes körü lekérdezése minden bizonnyal tovább árnyalta volna a kapott képet, és annyiban lehetett volna többet nyújtó a mostaninál, amennyiben ez a teljesség a helyi erö- és kapcsolati viszonyok feltárását is lehetővé tette volna. Erről végül is lemondtunk.

Az interjúk elkészítését a Babes-Bolyai Tudományegyetem politológus hallgatói vállalták, a lekérdezésre 2003 és 2004 nyarán került sor. ${ }^{5}$ Összesen 22 interjú készült, négy Gyímesben, hét Székelykeresztúron, öt Kalotaszegen, hat Pécskán.

A megszólaltatottak:

Gyímes: Rácz Árpád tanító, a Csángó Ifjak Középloki Közösségének alelnöke; László Jeremiás Miklós a gyímesközéploki Ordasok Hagyományörzỏ Néptáncegyüttes elnöke; Szilveszter Imre, római-katolikus plébános; Mihók Péter gyímesfelsőloki polgármester.

Székelykeresztúr: Hegyi Portik Kelemen római-katolikus plébános, a Kolping Egyesület vezetöje; Buzogány Levente, a Székely Ifjak Fórumának alelnöke; Szöcs Pál, a Domus Egyesület elnöke; Nagy István, a Petőfi Sándor Alapítvány kuratóriumának elnöke; Farkas Sándor családi orvos; Farkas Csaba RMDSZ-elnök; Benyovszki Lajos, Székelykeresztúr polgármestere.

Kalotaszeg: Ferenc László, kőrösföi lelkipásztor és kalotaszegi esperes; Tötszegi Tekla, a Mérai Hagyományörzők Egyesületének képvisełője; Molnár János profeszszor, a zsoboki Bethesda Gyermekotthon vezetője; Szentandrási István, Bánffyhunyad város alpolgármestere; Antal János, Körösfö polgármestere.

Pécska: Friedrich Rozália magyartanár, a Búzavirág Egyesület elnöke; Czeglédi Ferenc, római-katolikus plébános, a Kolping Család Egyesület elnöke; dr. Pálfi Sándor, orvos, a pécskai Kálmány Lajos Közmủvelődési Egyesület elnöke; Kovács Márton, vállalkozó, az Iparosok Egyesületének elnöke; Iustin Cionca, Pécska polgármestere; Nagy István, alpolgármester, a pécskai RMDSZ elnöke.

\section{A civil jelenlét és ismerete}

Nehezen mondható meg, hogy mekkora egy bizonyos helyi közösségben az optimális civil szervezetszám, ha egyáltalán beszélhetünk optimumról. Ismert tétel, hogy minél inkább tagolt, minél több szerveződés által képviselt és megjelenített egy helyi közösség, annál biztosabb, hogy „müködik”, hogy van, és lenni akar. Hogy nem sodródik az eseményekkel, hanem alakítani kívánja sorsát.

A vizsgált kistérségek mindegyike kicsiny lélekszámú összességében is, a központinak tekintett települések tízezer körüli lélekszámúak, míg Gyímes teljes lakossága sem éri el ezt a szintet. Ha figyelembe vesszük, hogy Romániában mintegy 25 ezer civil szervezet létéröl beszélnek, ${ }^{6}$ akkor ez azt jelenti, hogy mintegy 880 lakosra jut egy szervezet. Temes megyében 2002-ben 983 szervezetről voltak adatok. ${ }^{7}$ Mivel az utóbbi két évben a magyar szervezetek száma a megyében kb. 10\%-kal növekedett, ${ }^{8}$ ezt a növekedést kivetítve a megyére, alighanem 1050-1100 szervezettel számolhatunk. Ezek szerint Temes megyében 610-640 lakosra jut egy civil szervezet. Ugyanakkor az Erdélyi Magyar Civil Szervezetekért Alapítvány (ERMACISZA) adat- 
bázisában 2300 szervezetről vannak adatok, utóbbi szerint 650 romániai magyar polgárra jut egy civil szerveződés. A magyar szervezetszám az országos átlagnál magasabb, egy fejlettnek számító megye átlagánál kevéssel alacsonyabb. Ugyanakkor vegyük figyelembe, hogy ezek az adatok a beírt és nem a valóban müködö szervezetekre vonatkoznak.

A kutatásban említett civil szervezetek száma 39. Három kistérség esetében a kutatás általi adatok ellenörzésére kikértük az ERMACISZA adatait." Eszerint: A Gyímesekben hat szervezetet írtak be, Kalotaszeg négy szervezettel ${ }^{10}$ szerepel, a legnagyobb különbség Székelykeresztúr és térsége vonatkozásában mutatkozik, a városból 29 szervezetet vettek fel az erdélyi magyar listára," ugyanakkor három szervezetről van adat a kistérség falvaiból.

\section{TÁBLÁZAT}

A vizsgált térségekben található civil szervetek száma (The Number of Civil Organisations in the Region Analysed)

\begin{tabular}{lccccc}
\hline \begin{tabular}{c} 
Szervezettípus/ \\
\multicolumn{1}{c}{ Térség }
\end{tabular} & Gyímesek & $\begin{array}{c}\text { Székely- } \\
\text { keresztúr }\end{array}$ & $\begin{array}{c}\text { Kalota- } \\
\text { szeg }\end{array}$ & $\begin{array}{c}\text { Pécska } \\
(M+R)\end{array}$ & Összesen \\
\hline Oktatási & - & 3 & - & - & 3 \\
Múvelödési & 2 & 4 & 3 & $2+1$ & 12 \\
Ifjúsági & - & 4 & - & - & 4 \\
Szociális & - & 7 & $2 *$ & $0+1$ & 10 \\
Egyházi** & - & $2+1$ & 1 & - & 4 \\
Gazdasági & 1 & 2 & - & $1^{* * * *+0}$ & 4 \\
Környezetvédö & - & - & - & $1^{* * * *+0}$ & 1 \\
Településfejlesztés & - & - & - & $0+1$ & 1 \\
RMDSZ**** & 1 & - & - & 1 & $(+2)^{* * * *}$ \\
\hline Öszzesen & $3(+1)$ & 23 & 6 & $7(+1)$ & $39(+2)$ \\
\hline ERMACISZA & 6 & $29+3$ & 4 & & \\
Szervezetszám & 6 & 32 & 6 & 7 & 51 \\
\hline
\end{tabular}

* Zsobokon egy jogi keretben két intézmény, az Idősek Otthona és a Gyermekotthon működik, és ez nem szerepel az ERMACISZA adatbázisában.

** Egyházi szervezetnek tekintettük a Kolping családot és a Caritast, és ide vettük azt az apácát, aki egymaga végez karitatív munkát.

*** Ezek a szervezetek magyar kezdeményezésre jöttek létre és vezetöik is magyarok, de mindkettönek vannak román tagjai.

${ }^{*} * * * A z$ RMDSZ civil szervezetként való minösítése nem tekinthető tévedésnek, amennyiben az ałapító szándékot vesszük ałapul. Müködése alapján minősül pártnak.

Forrás: Kistérségi civil kutatás.

Pécska térségét 13 ezer fövel, ${ }^{12}$ Kalotaszeget 20 ezerrel, Székelykeresztúr térségét szintén 20 ezerrel és a Gyímeseket 10 ezerrel számolva, a vizsgált térségre 65 ezres lakosság jön ki, miszerint 1275 före jut egy civil szervezet. Ez a szám csak viszonylag magas, ugyanis a tapasztalat az, hogy a civil szervezetek többnyire a nagyobb városokban koncentrálódnak. A Temes megyei szervezeteknek a 75\%-a múködik a 
megyeszékhelyen, miközben ennek lakossága a megye lakosságának a felét adja. Ez annak a jele, hogy a civil szervezödések létrejötte jelentös mértékben humáneröforrás-függö, ami a központba koncentrálódik. Ezt figyelembe véve a kapott eredmény jónak mondható.

Az egyes kistérségek közötti különbségek is jórészt azzal magyarázhatók, hogy a térségközpont önmagában mennyire erös. Keresztúr hagyományosan térségközpont, s ezt ốrzi napjainkig. Bánffyhunyad is az, Kalotaszeg vonatkozásában, bár itt a megyésítés zavarta meg pár évtizede a helyi térségi kapcsolatokat azzal, hogy nem a történelmi tájegységi határon húzták meg a megyehatárt. Továbbá itt nem rendelkezünk a román civil szférára vonatkozó adatokkal, ezek beszámításával mindenképpen más volna, javulna a helyzet. Pécska mindmáig nem vált igazi kistérségi vonzásközponttá, a Gyímesek pedig mindig a forrásszegény körzetek közé tartoztak.

A továbbiakban azt nézzük meg, a civil vezetök és általában a helyi elit mennyire tájékozott a civil szervezetek létét és tevékenységét illetóen. Az interjúk során a 22 megkérdezettböl senki sem sorolta fel az interjúalanyok válaszai alapján kialakult lista minden tételét. A helyzetismeret fordított arányban áll a szervezetszámmal, százalékban kifejezve a legkevesebb szervezetet Székelykeresztúron említettek. A helyzet ismerete ugyanakkor jónak mondható, hiszen 51-böl 39 szervezetről említést tettek a megkérdezettek, ami 76\%-os ismertséget jelent. Százas esetszám mellett már nem is lehet elvárni a teljes körü ismertséget.

A megkérdezetteket négy csoportba osztjuk: civil vezetók, egyházi emberek, véleményvezérek (orvos, pap, gyógyszerész, tanár) ${ }^{13}$, helyi politikusok (2. táblázat). A csoportok között nincsenek kemény határok, ugyanis az egyházak mellett müködö szervezeteknek többnyire papok a vezetöi, véleményvezér tagja lehet több szervezet vezetőségének, miként a polgármester és/vagy alpolgármester is olykor hivatalból lesz tagja egyik vagy másik szervezet vezetőségének.

\section{TÁBLÁZAT}

Az interjúalanyok csoportbeosztása (The Groups of the Interviewed Persons)

\begin{tabular}{cccccc}
\hline Interjúalanyok & Civil & $\begin{array}{c}\text { Egyházi } \\
\text { (+civil) }\end{array}$ & $\begin{array}{c}\text { Vélemény- } \\
\text { vezér }\end{array}$ & $\begin{array}{c}\text { Politikus } \\
\text { (Önkormányzati, } \\
\text { RMDSZ) }\end{array}$ & Összesen \\
\hline Gyímesek & 2 & & 1 & 1 & 4 \\
Székelykeresztúr & 3 & 1 & 1 & 2 & 7 \\
Kalotaszeg & 2 & 1 & & 2 & 5 \\
Pécska & 3 & 1 & & 2 & 6 \\
\hline Összesen & 10 & 4 & 1 & 7 & 22 \\
\hline
\end{tabular}

Forrás: Kistérségi civil kutatás.

A 3. táblázatba foglalt számok sorrendet mutatnak: a helyi civil szféra ismeretét aszerint, hogy az interjúban a megkérdezettek hány szervezetet említettek meg. 


\section{TÁBLÁZAT}

Az interjúk során emlitett szervezetek száma

(The Number of the Mentioned Organisations in the Interviews)

\begin{tabular}{ccccc}
\hline Interjúalanyok & Civil & $\begin{array}{c}\text { Egyházi } \\
\text { (+ civil) }\end{array}$ & $\begin{array}{c}\text { Vélemény- } \\
\text { vezér }\end{array}$ & $\begin{array}{c}\text { Politikus } \\
\text { (Önkormányzati, RMDSZ) }\end{array}$ \\
\hline Gyímesek & 2 & & 2 & 1 \\
Székelykeresztúr & 4 & 3 & 2 & 1 \\
Kalotaszeg & 2 & 2 & & 1 \\
Pécska & 2 & 2 & & 1 \\
\hline
\end{tabular}

Forrás: Kistérségi civil kutatás.

$\mathrm{Az}$ eredmény várható volt: a civil vezetőknek van a legkevésbé rálátásuk az egészre, és a politikusok ismerik a leginkább a helyzetet. ${ }^{14}$ De még esetükben sem lehet teljes helyzetismeretröl szólni: egyikük sem említette meg valamennyi létezö szervezetet. A székelykeresztúri polgármester 13 szervezetet említett, a teljes számnak alig a felét, illetve nem is utalt a városban müködő szervezetek összlétszámára.

\section{Kezdeti lépések}

Egy civil szervezet létrejövetele egyfajta találkozás eredménye: a létezö, többékevésbé világosan tagolt igény mellé jelentkezik egy személy, egy szervezet, aki(k) létezö feladatai(k) mellett vállalja(ák) az újabbat. Fontos és vizsgálandó kérdés, a civil szervezetek milyen impulzusra jönnek/jöttek létre, továbbá az, hogy ki(k) az(ok), aki(k) az élére állt(ak) egy ilyen folyamatnak, és végül fontos, hogy kik miként támogatták a kezdeményezö(ke)t.

Mivel az esetszám nem teszi lehetővé a kvantitatív elemzést, az interjúkból vett szövegrészekkel mutatjuk be a helyzetet. Minden megkérdezettnek minden kérdést feltettek a kérdezöbiztosok, mindenki mindenre válaszolhatott. Az idézett szövegek forrását betúkóddal jelöljük. ${ }^{15}$

A civil szervezeteket a megalakulás körülményeit illetően két csoportba sorolhatjuk: amelyek világos feladattal, létező minta vagy modell ismeretében jöttek létre, illetve azok, amelyek esetében valamilyen véletlen esemény, körülmény hatott, $s$ arra is van példa, hogy a kezdeti tevékenység késóbb másodlagossá vált.

„A Bethesda Gyermekotthon az árva, félárva és terhelt családokból származó gyermekek mellett gondozásába veszi azokat a szórványgyermekeket is, akiknek lakhelyükön nines anyanyelvŭ iskolázási lehetőségük és a városon való anyanyelvü iskoláztatásuk, vagy épp a lakhelyükről az iskolába való naponkénti ingázásuk fizikailag és anyagilag egyaránt lehetetlen. Az iskolai év idején ezek a gyermekek is az otthon lakói. A Zsoboki Református Egyházközség nőszövetsége régóta nyaraltat árva gyermekeket családoknál. A gyülekezet presbitériuma 1992 öszén a parókia mellett ingatlant vásárolt az otthon számára. 1993 tavaszán a gyülekezet önerőből hozzáfogott az iskola javításához, korszerüsítéséhez és a megvásárolt telken levő romos épület átépítéséhez. 1994. szeptember 18-ára készült el az otthon első épülete 30 gyermek számára, majd felépült az 1994. február végén elkezdett új, 55 gyermeket befogadó központi épület, 1996-ban. Az új iskolaépület tornateremmel, 3 tanteremmel és óvodai helységgel 
1998-ban lett készen. Az Idősek Otthona a zsoboki gyülekezet újabb diakóniai munkáját és szolgálatát jelenti. Ezzel a céllal kezdôdött el Farnason 1997-ben az otthon építése, elöször a telken lévő udvarház felújítása, majd az új épuilet alapvetése és felépítése. Az Idösek Otthona ugyanabban a jogi keretben szerveződik és müködik, mint a Bethesda Gyermekotthon." (K-3-C)

„A kőrösfői Rákóczi Kulturegyletben fiatalokat tanítunk táncolni. Táncegyüttesünk több alkalommal is volt külföldön, Budapesten, Ausztriában, Mödlingben, 2003 szeptemberében is voltak Magyarországon. Mikor alakult az Egyesuilet? Valamikor a kilencvenes években, öszintén szólva már nem is tudom, olyan rég volt. Tulajdonképpen úgy kezdődött, hogy egy németországi várossal testvéri kapcsolatunk van. Ők felajánlottak egy autót, 3-4 tonnásat, amivel szállítani tudunk, kiszolgáljuk vele az embereket, s azért volt alapítva, hogy az autót be tudjuk hozni az országba. Így, ez azt lehet mondani, hogy állandó használatban van, szállításra, teherszállításra, amire szüksége van a falun beliul az embereknek." (K-5-P)

„Ezt a szervezetet én kezdeményeztem és hoztam létre. Tiszta suhogó egyedul. Ja, ketten, a feleségemmel... Az egész onnan kezdödött, hogy elvoltunk egyszer szilveszterezni Magyarországra, elvoltunk egy táncpróbára, megtetszett, hazajöttünk, csináltam egy tánccsoportot, s kész. Hogy tudjunk érvényesuilni, bejegyeztettem a táncesoportot úgy, mint ifjúsági szervezetet. Be van jegyezve, 2003 decemberében kaptuk meg a törvényszéki végzést, most már hivatalos. A szervezet Budapesten is be van jegyeztetve." $(\mathrm{Gy}-2-\mathrm{C})$

$\mathrm{Az}$ idézett szövegek érzékeltetik, hogy általában a szociális feladatra vállalkozó szervezetek esetében létezik világos képlet, program, a konkrét elképzelések hiánya, az interjúk szerint, az ifjúsági szervezetekre jellemző. Megtörténik, hogy egyfajta belső fejlődés végső eredménye a civil szervezet megalakulása.

„Kezdeményezés már régebben is volt, csak nem konkretizálódott. A helyi értelmiségiek álltak össze a kultúrigazgatóval, meg pár fiatallal, aki úgy érezte, kell változtatni a pangáson, ami van a kỏzségben. Tehát úgy éreztük, kell egy fórum, ami összefog bennünket, közösen tudunk tenni egy cél érdekében valamit, ez 1999 végén, 2000-ben kezdett el mocorogni bennünk és a Csángó Ifjak Középloki Közössége jogi személlyé 2002 januárjától lett, 2002 januárjától vagyunk hivatalos jogi személyek." (Gy-1-C)

Van, amikor közvetlen külföldi hatás indítja el, s a külföldröl jövỏ támogatás határozza meg a szervezet életét. A kilencvenes évek elején fedezi fel Nyugat, hogy mi volt a diktátori álarc mögött, például a gyermekvédelem területén. A nyugati sajtó tele volt szörnyúséges történetekkel, emberek és szervezetek sora ajánlotta fel segítségét.

„A Domus egyesület számára egy példa volt a bautzeni egyesület. 1990-ben, amikor létrejött, kimondottan azért hozták létre, bautzeni emberek, lelkes emberek, hogy a Gyerekotthonban lévő gyermekek életét könnyítsék és színesebbé tegyék, változatosabbá. Ilyen segélyegyesületekról mi is hallottunk addig, de lényegében nem tudtuk, hogyan müködik, Az egyesület maga keresztúri kezdeményezés volt, de saját erönkböl nagyon kevésre tudtunk volna menni, mivel az állami támogatás abban az időben, a kilencvenes évek elején egyesületek, szervezetek számára nulla volt. A németországi segítséggel és kisebb mértékben, de angol segítséggel is müködöképessé vált ez az egyesület, lakásokat tudtunk bérelni, egy kis bizonyos szintü ellátásban tudtuk részesíteni az otthonból kikerült fiatalokat, akik így nem kényszerültek arra, hogy lopjanak, 
tekeregjenek, raboljanak és eladják magukat, például a lányok nem szorultak arra, hogy prostituáltak legyenek." (Sz-3-C)

„A Ház a holnapért Alapítvány szintén a gyerekotthonnal kapesolatos és az onnan kikerülö gyerekeknek nyújtana otthont, egy ilyen rendezett családi mintát próbálna utánozni, ahol nevelők felvállalják a gyerekeknek, különbözö életkorú gyerekeknek akár egy családi mintát utánozva ezeknek a gyerekeknek a nevelését. Anyagi segítséget nyújt nekik, pótolja azt a szülót, aki nekik hiányzik, akihez az ember, amikor bajba keriil, akkor visszakanyarodik." (Sz-5-V)

.A Ház a Holnapért Alapítványnak Németországból volt a kezdeményezés, és németországi példák és romániai példák alapján szerveződött. A pénz teljesen Németországból jött, a házak vásárlására is onnan jött a pénz. Németországból fiatalok érkeztek, ottan szerzett pénzből fizették öket, de nem csak azt, hanem fizették a felmerülő kiadásokat is, mint például egy kirándulás finanszírozása vagy ünnepnapokon az ajándékokra a pénzt innen kapták a gyerekek, vagy ha ök vásároltak be, a németországi pénzből vásároltak a gyerekeknek, vagy egy fözéshez alapanyagot szintén csak németországi pénzből vásároltak. Most az alkalmazottak itt az államtól kapják a pénzuiket. de a szervezetet nagyobbrészt most is németek támogatják, csak nem szólnak bele a tevékenységébe, a német támogatók csak a pénzügyi elszámolást várják. A szervezet irányítására létezik egy kuratórium, amely úgy ritkán, de összejön és ellenörzi az ott folyó tevékenységet. Én is tagja vagyok ennek az egyesületnek, vezetőségnek, és mondhatom, hogy jó munka folyik, bár kevésbé ismert." (Sz-3-C)

Ilyen jellegü és komoly volumenủ külföldi segítségek okán alakult ki az a romániai gyakorlat, amely mindmáig csak szociális téren múködik: az állam partnerként fogadja el a szociális feladatokat (át)vállaló civil szervezeteket, bizonyos költségeket - fizetést például - közpénzekből állnak. A mủvelödés területén ilyen együttmüködésre nincs példa, pedig olykor mindenki nyerne belöle.

„A Petófi Sándor Kulturális Alapítuány nem kulturális alapítvány, hanem azzal a céllal jött létre, hogy felépítsen egy müvelödési házat itt Székelykeresztúron. 1995-ben jött létre pontosan, aztán ez úgy néz ki, hogy a mostani anyagi körülmények az építkezést nem teszik lehetővé, tehát inkább egy más irányba indultunk el. Hát meg szeretnénk szerezni a mozit például, és azt átalakítani egy ilyen mủvelődési központtá, úgy, hogy manzárdot húzni rá, tehát megvannak az elképzeléseink. Most folyik éppen az akció és harcolunk, hogy megszerezzük ezt az épületet, ugyanis egy új épületet építeni, vannak elöre felméréseink, számításaink, hát 25-30 milliárd lejbe kerülne, jelen pillanatban nem tudna belevágni sem a város, sem az egyesület, sem a megye ilyesmibe." (Sz-7-P)

Arra is van példa, amikor valamilyen politikai-társadalmi folyamat hívja életre a szervezetet, például egy ingatlan visszaszerzésének a lehetősége indítja el, illetve újra a tevékenységet.

„Az Iparosok Egyesületét elöször a 19. század végén hozták létre Pécskán, a huszas évektöl kủlön román és külön magyar intézmény müködött. Újraindítását Bán Béla kezdeményezte 1992-ben, ö később félreállt, de sikerült elérni, hogy az egykor mủködött szervezet jogutódjaként visszaszolgáltassák az államosított ingatlant." (P-6-P) 


\section{Kivel, merre, kiért?}

A civil szervezetek tevékenységének elindulása meghatározó lehet, a forrásszegénység körülményei között fontos, hogy milyen módon képesek kilépni a nyilvánosság elé. Ennek az is összetevője lehet, hogy honnan és miként toborozzák az alapító tagokat.

„Az Ordasok Hagyományörzö Néptáncegyüttes indulásakor összeszedtem a testvéreket s unokatestvéreket, először csak ennyien voltunk. Mi testvérek vagyunk négyen. unokatestvér 7-8, úgy, hogy az már egy tánccsoportot kitett. Egyelöre még csak az alapító tagok vagyunk, az 13 személy, de viszont ha a szükség úgy követeli 40-en, 50 -en is mozdulunk." (Gy-2-C)

Az indulást persze nem lehet megkoreografálni, bár van arra példa, hogy kimondottan látványosra sikerül a helyi közösség elötti bemutatkozás.

„A Csángó Ifjak Középloki Egyesülete, ennek az első megmozdulása, a házhoz járó Mikulás, ez szociális ugye. A szülők igénylése szerint egy lajstromot állítottunk össze, s az egész községet bejárták. Nem egy, mert az teljesen lehetetlen, hogy egy Mikulás teljesen bejárja az egész községet, hanem három csoportra oszlottak, a gyerekek örömére persze. Kezdeményezték még a gyereknapoknak a megszervezését, első évben megszervezték, aztán úgymond kivették a kezükből. A múvelődés, a kultúrtevékenység a változások után nagyon elhanyagolódott, a forradalom utáni időszakban azt lehet mondani, hogy nem volt. (Gy-4-P)

Érdekes, és nem minden szerepzavar nélküli, amikor mint jelen esetben, egy község elsô vagy második embere azon ügyködik, hogy tettrekész fiataloktól elvegyenek valamilyen általuk kezdeményezett rendezvényt, amely ráadásul élénkítette az amúgy nem igazán színes múvelődési életet. Ugyanakkor van, akitől nem lehet semmit elvenni, teszi a dolgát. Igaz, annyi ,jó” kijár neki, hogy szolgálattételében nem akadályozzák.

„Fenianda növér. Nem tudom pontosan, azt hiszem egyházi szervezetet képvisel, valamilyen svájcit. Katolikus, szóval apáca, és az egyik leglelkesebb ember, akit itt a környéken láttam. Elmegy. felkutat szociális eseteket, nemcsak itt Keresztúron, hanem a környezö falvakban is, és segít, és föleg nem veri nagydobra, az ember csak úgy hallja, hogy ezen is segített, annak is kifizette a házbérét, ennek is besegített, a másiknak is besegített. Egy müláb kellett valakinek, ami borzasztó sokba került, abba is besegített, de hát, mint az önzetlen segítỏ emberek, ő segít és hallgat. Mert van, aki keveset tesz, és nagyon nagydobra veri, a másik pedig önzetlen ember, csinálja, csinálja és hallgat vele." (Sz-5-V)

Az egyházi vagy egyházakhoz kapcsolódó szervezetek helyzete annyiban előnyösebb, hogy nem, vagy ritkán számítanak környezetük, a helyi hivatalosságok segítségére. Ugyanakkor mögöttük áll az egyháznak, mint közösségi intézménynek a tagadhatatlan tekintélye.

„Caritas szervezetnek a helyi kirendeltjei, itt most pillanatnyilag ketten vannak Keresztúron, ők a mi munkánkat, az orvosok munkáját próbálják segíteni azzal, hogy az otthon ágyban fekvő krónikusan elfekvő betegeknek a mindennapjait próbálják megkönnyíteni, kezelésekkel, lelki támasszal, kinek mire van szüksége, házimunkába 
való besegítéssel és ilyen dolgokkal. Ugyanakkor adományokat, segélyeket is osztanak. A Caritas csoport olyan 25 tagból áll, az egyházközség keretén belül müködik. $(\mathrm{Sz}-5-\mathrm{V})$

„A Kolping Család Egyesületnek 260 belsö tagja van. Nyitott szervezet, állandóan múködik, szociális és egyházi tevékenységei vannak, igaz, már zárt is ki tagokat. Az ifjúság köréböl kerül ki a legtöbb tag, de a nyugdíjasok, háziasszonyok is sokat segítenek. Asztalosmühely, sportkör is múködik a keretén belül." (P-2-C)

Különben szociális téren nem minden program problémamentes. És nem arra utalunk, hogy a segélyt osztót általában bírálat éri, mert nem jut mindenkinek, soha nincs a segélyböl elegendő. Sokkal inkább arra, hogy a rászoruló és a segélyt nyújtó elképzelései olykor nem találkoznak. A segélyprogram indítója hosszú távú változást szeretne elérni, miközben a rászoruló ritkán hajlandó oonnön helyzetét illetỏen távlatokban gondolkozni.

„Az Omega Alapítvány elsősorban a roma lakosságot próbálná segíteni, egyrészt a felemelkedésuiket, tehát anyagi segítséget, másrészt pedig az integrálódásukat a társadalomba. Ezt olyan formán képzeltúk el, hogy látva az elején, hogy az anyagi segítségek azok olyanok, mintha egy feneketlen zsákba bújnának belé, és nem mindig azt a célt szolgálták, amit mi szerettünk volna. Akkor jött egy olyan, hogy próbáljuk öket munkára nevelni, hát nem azért nem dolgozik, mert nem szeret dolgozni, hanem nincsen munkahelye szerencsétlennek. Ezen próbáltunk volna változtatni, olyan értelemben, hogy földet bérelt az Omega Alapítvány, s az elején még a szántást, vetést is megoldotta, ök csak meg kellett munkálják, begyüjtsék a termést, és az az övék volt. Na hát ez az utóbbi egy-két évben kezdett sántítani, mert valami gond volt a földek bérlésével. De nagyon úgy nézett ki, egy pár éven át nagyon úgy nézett ki, hogy lelkesednek is érte, hát egy-két kivételtöl eltekintve végül is meg is dolgozták azt a földet, lett termésük is, és élvezték is annak a gyümölcsét." ( $\mathrm{Sz}-5-\mathrm{V}$ )

„Ez az Omega egy aránylag jól múködö program volt, és a segítségnyújtás mellett egy kicsit hozzájárult ahhoz is, hogy ezek a cigány emberek egy kicsit közeledjenek a munkához is, ne csak a sült galambhoz. Persze, természetesen még mindig müködik, most a legújabb terv az, hogy Fiatfalván a Kárahegyen megoldja a vízvezeték problémáját, a vízbevezetést a Kárahegyre, tehát a cigánycsaládoknak. Természetesen kỏzỏsen az önkormányzattal, hiszen nagy beruházás. Úgy néz ki, hogy a nagyobbik részt felvállalja, s akkor meg tudjuk oldani. Vannak még némi viták, hogy hogyan, mert ugye nem mindegy, hogy megvan a víz, aztán meg ki fizeti. Vannak ilyen gondok is, hogyha a víz meg folyik a csapból, aztán ki fizeti, meg ki vigyáz rá, de gondolom letisztázódnak ezek a dolgok, és akkor elindulhat, ki lehet vitelezni ezt a programot, amit nagyon kérnek az ott lakók, és mi is úgy lássuk, hogy ez fontos dolog, hiszen jelen pillanatban az ivóvíz eléggé gyatra minöségü, amit ök használnak." (Sz-7-P)

Minden szervezet, minden ember számol bizonyos eredménnyel, amikor egy tevékenységet elkezd. Csakhogy vannak olyan esetek, amikor az eredményt nem lehet teljességében előre látni, még kevésbé bebiztosítani.

„A német társszervezetünkkel és egy másik németországi szervezettel azon gondolkodunk, hogy bővítsük a Domus tevékenységét, hogy más fiataloknak is, olyanoknak is, akik nem részesültek valamilyen támogatásban, lehetőségük legyen a Domushoz hasonló támogatást kapni, hogy jobban be tudjanak illeszkedni a társadalomba, ne veszszenek el, hogyha a szuilők elhagyták ôket, ne legyenek a társadalom számára elveszett emberek. Nem mindenkit tudunk megmenteni, sokszor nem is a pénzen múlik, hanem 
a fiataloknak a nevelésbeli hiányosságain, vagy a jellembeli hiányosságaikon, a 200 fiatalból 10 fiatalunk van, aki rendszeresen visszalátogat a Zöld Péter 2-es számú intézménybe, ez Csíkszeredában a börtön." (Sz-3-C)

A mủvelődés területén általában elvárásról beszélhetünk. Ezek a szervezetek világos és pontokba szedhetỏ programmal indulnak, s számukra előnyös, hogy viszonylag kevés pénzböl képesek élményt nyújtó programokat szervezni.

„A Kálmány Lajos Közmüvelödési Egyesület 30 tagot számlál, a közınüvelödés tekinthetö fö tevékenységének. Kirándulásokat szervez, mind a fiatalok, mind az idősebbek számára, mủveltségi vetélkedóket szervez, különbözö kiadványokat jelentet meg, eddig négy könyvet adott ki, köztük Pécska történetét, Kovács Géza tollából. Emléktáblát leplezett le, szobrot álított, megszervezte és támogatta a Búzavirág néptáncegyüttes belgiumi útját. Átlagban 300 résztvevövel kell számolni egy nagyobb rendezvényen, a tudományos üléseken átlagban 80 érdeklódő jelenik meg." (P-3-C)

$\mathrm{Az}$ is fontos, miként viszonyul a helyi - kulturális, társadalmi, politikai - elit egy ilyen szervezethez. Amennyiben mellé áll, szinte biztos a siker.

„A Kálmány Lajos Közmüvelödési Egyesületet az alpolgármesterrel és a római katolikus plébánossal együtt hoztuk létre, nevét a századforduló táján a településen müködő plébánosról kapta, aki sokat tett a közművelödésért, népköltészetet gyüjtött, ki is adta annakidején." (P-3-C)

„A Kós Károly Kulturális Egyesületnek tagja vagyok. A társaság tagjai 30-54 év között mozognak. Fontosnak tartottuk, hogy ezt az egyesületet fiatalok vezessék a segítségünkkel, mert úgy gondolom, a jövöt biztosítani kell, s ha valamilyen formában fiatal korodban megkapod az ízét a rendezvények szervezésének, akkor folytatni fogod. Ez pedig nagyon jó, hiszen szükség van a fiatalokra." (K-4-P)

Ugyanakkor a mủvelödési szervezetek egyfajta tükröt is tartanak a helyi közösség elé: nem kizárólag egy ilyen szervezetet minösít az, ha elhatalmasodik az érdektelenség, ha a célok és eredmények nincsenek összhangban, bár az is tény, sokan kellö felkészültség, tapasztalat hiányában vállalnak közösségi szerepet és felelösséget. Illetve, ismert képlet, hogy a szomszéd kertje mindig érdekesebb. Másoknak könynyủ tanácsot adni.

„A Kós Károly Bánffyhunyadon van, itt élek egy szomszédos faluban, de jól ismerem. Müködöképes, nagy terveket szőttek. Nemrég voltak megtartva a Kós Károly Napok, szép kis ünnepséget rendeztek. Bánffyhunyadon, Kalotaszegnek egy kulturális központot szeretnének létrehozni. Alszeg. Felszeg. Cifrapalotaszeg mind bele lenne fogIalva. Én bíztattam öket, amennyiben tudom, támogatom öket, mint polgármester, de mint egyszerú személy is mellette vagyok, mert gyönyörü elgondolás van kilátásban. Nagyon sokan megijedve elbátortalanították a fiatalokat. Egyszerüen rájuk szóltam, hogy nem szabad, mert a fiatalságot bíztatni kell, nem pedig visszarántani. Meg kell próbálni, mert ha látják, hogy csinálunk valamit, ami jó nekünk is, magyaroknak, akkor azt kell csinálni. Voltak olyanok, akik azt mondták, hogy az önkormányzat is segíthetne. De honnan, miből? Tény és való, hogy a bánffyhunyadi alpolgármester úr még fiatal, valószínủ nem tudja hogyan. Én azt mondtam, hogy ha akarnak támogatni egy célt, közösséget, akkor azt az önkormányzat is tudja, s ha ök nem tudnak orvosságot, akkor én majd adok rá. Én majd támogatom öket bármivel, anyagiakkal. Jó kis társaság van ott. S ennek így kellene müködnie Erdélyben, anyagiakban s lelkiekben támogatni, ha akarunk valami kibontakozót, mert úgy apadunk, mint a fehér holló. (K-5-P) 
Az ifjúsági szervezetek kérdése talán a legbonyolultabb. A politika szereplöi többnyire elvárják, hogy támogatóikként, szinte kiszolgálóikként legyenek jelen, s akkor kerül némi támogatás. Ha a függetlenséget választják, nagyon kell küzdeniük. Ugyanakkor a fiatalok igényesebbek, szervezetüktől akármit nem fogadnak el, erős a kritikai szellem.

„A Csángó Ifjak Középloki Közösségének célja elölendíteni a fiatalok életét, tehát értelmet vinni a fiatalok életébe, hogy ne csak egy hétvégi bulizásból álljon az egész, hanem legyen más. Egy teleház létrehozása volt a legfontosabb, ez most már meg is van, szerencsére. Kulturális dolgok felölelése, hagyományörzés és tartalmas időtöltés biztosítása a helyi fiataloknak, ez kellene. Szervezetünknek jelenleg 29 tagja van, de a 29 tagból, aki szervesen részt vesz a dolgokban. az. 10 alatt van." (Gy-1-C)

„A Székely Ifjak Fóruma 1990-ben alakult meg, az akkori alapító tagok közül most már csak Kis József, aki a jelenlegi elnök, és Kacsó Csaba, ök vannak. 1990 öszén jegyezték be hivatalosan, tehát hivatalosan bejegyzett szervezet. Szívhang - ez volt a saját újságja. Irodahelysége is volt, tehát egy komoly szervezet volt, ami százon felül számlálta akkor a tagokat. A tevékenység ifjúsági, hát a forradalom után ez a friss, újpolitikai. Aztán lefagyasztódott az egész, leállt, a tagok kezdtek széthúzni, történt egy nézeteltérés a vezetöség között, pártokra szakadtak széjjel, Négy évvel ezelōtt alakult meg újra, egy egészen új, egy egészen fiatalabb csapattal. Az új, ami bár nem számlál annyi tagot, elég jól müködik, most egy kicsit meg volt állva az irodahelyiség berendezése miatt, az infrastruktúra beszerzése miatt. Állandó tevékenységsorozatot nem tudunk, tervezetünk van, de nem tudjuk egyelöre megvalósitani." (Sz-2-C)

Az iskolák mellett müködő civil szervezetek képlete pedig talán a legegyszerübb: az iskola tevékenységének támogatása közvetve - tanulóknak ösztöndíj és más juttatások formájában -, illetve közvetlenül, például az oktatási folyamathoz szükséges eszközök (számítógépek) beszerzésével. És ez a tevékenység többnyire hatékony, a támogatás folyamatossága megfelelö kapcsolattartással biztosítható.

„A Zeyk Domokos Egyesïlet segítségével igyekszünk támogatni az iskola munkáját, olyan értelemben, hogy berendezést szerezni számára, anyagi és erkölcsi támogatást szerezni számára úgy a város lakóitól, mint külföldi iskoláktól vagy egyesültektôl. Mivel új az iskola, a megszünỏ Gyerekotthon a városi pénzek nagyobb részét elviszi, és így ez az új iskola elég szükösen rendelkezik anyagi javakkal. Ahhoz, hogy jó, hatékony oktatás folyhasson, kell egy bizonyos szintú ellátás bármilyen iskolában, s ennek az egyesületnek az a szerepe gondolom, hogy több éven keresztül felvállalja az itt folyó munka támogatását, az iskola nevelöi, oktatói munka támogatását. Az egyesületekre azért is van szükség, mert nehéz támogatáshoz jutni állami intézményeknek. Nagyon sok esetben állami intézmények nem pályázhatnak, vagy ha pályáznak is, nem fogadják el a pályázataikat, ezért is szükséges egy ilyen egyesület létezése az iskola mellett." (SZ-3-C)

Figyelmet érdemel, hogy a vizsgált szórványban, illetve erös kisebbségi léthelyzetben (Pécska, Kalotaszeg, Gyímesek) nem jöttek létre a helyi iskola támogatását vállaló civil szervezetek. Ennek egyik lehetséges magyarázata az, hogy a térségekben közös, tagozatos iskolák vannak, s ezeknek a támogatása nem szorítkozhat csak a magyar tagozatra. 


\section{Források, támogatók, technikák}

Vannak szervezetek, amelyek esetében a forrásszerzés nem létkérdés, és vannak olyanok, amelyek támogatás hiányában rövid idön belül lehetetlenné válnak. Egy müvelödési, ifjúsági vagy oktatási célokat szolgáló civil szervezet források hiányában nem kényszerül tevékenysége felfüggesztésére, olyan tevékenységre áll át, amit elsősorban az önkéntességre alapoznak. Megemlékezéseket, szabadegyetemi elöadást, de akár ifi sporttalálkozót is lehet pénz hiányában rendezni - mindig kerül annyi megértés, hogy kinyitnak valahol egy termet, a többi pedig munka kérdése.

„Hát ez az önkormányzat segítsége, hogy mi, az Ordasok a megállói kultúrban táncolhatunk, ott próbálhatunk, $s$ ő is biztosított székhelyet." (Gy-2-C)

„A Székely lfjak Fóruma pénzügyi támogatása önköltségi (?!?) alapon müködik, plusz pályázati pénzek. Van tanácsosunk, tanácsosaink voltak pontosabban, akik képviselöi illetményükből fizettek. Most nincsenek. A tagok tagsági díjat fizetnek, plusz, hogyha valami rendezvény jön, akkor pályázunk. A Soroshoz, az Illyéshez, a magyar Ifjúsági és Sportminisztériumhoz." (Sz-2-C)

Mủvelődési szervezetek esetében a külön programok, egy emléktábla, egy könyv kiadása, egy külföldi előadó meghívása jelenti azt a tevékenységet, amelyre pénzt kell szerezni. Az viszont általánosan jellemző, hogy hosszabb távra nem tudnak tervezni, mert a pályázati támogatásokra teljes biztonsággal számítani nem lehet.

„A Kálmány Lajos Közmüvelödési Egyesület helyben eseti támogatásokra és a minimális tagdíjakra számíthat. Nagyrészt a Communitas és az Illyés alapítványoktól pályázati úton megszerezhetỏ támogatásokból müködünk." (P-3-C)

„A pénzeket a Csángó Ifjak Középloki Közössége mind pályázati úton szedjük össze... A legnagyobb támogatónk az Illyés Közalapítvány. A Megyei Tanácstól jön pénz, a Communitastól, hát nem sok, nem kell azt eltúlozni, mert nem olyan túl sok, de a kereteknek megfelelően. Végül is, azt csináljuk, amire pénzt kapunk, ez magyarul így szól. Még a Nemzeti Kulturális Örökség Minisztériumához pályáztunk, de onnan nem nyertünk, de még megpróbáljuk. Mindenféle pályázati lehetốséget kipróbálunk, ahonnan az ifjúsági szervezeteket támogatják, azt mind, rendszeres pályázatfigyelönk van." (Gy-l-C)

Az egyházi szervezetek támogatása sokkal szélesebb körü, jelentős mértékben számíthatnak külföldi (testvér)szervezetek adományaira. Ez természetes, ezt adja a helyzet logikája, amit, ha a szociális védelem rendszerének a globalizációjaként fogunk fel, akkor ez azon ritka példák egyike, amikor örülni lehet a globalizációnak.

„A Kolping esetében a támogatások 60\%-a külföldről, Németországból származik, föleg a rendezvényekre küldik. A helyi támogatások $50 \%$-a nem pénzbeli, hanem étel, ital, kétkezi munka formájában érkezik, a többit az önkormányzat, pályázatok, adományok képezik." (P-2-C)

„A Caritas van, amit öneröböl tesz, és van, amit közvetve. Kapja a segélyt külföldi egyházközségektöl, vagy esetleg itt belföldröl, az egyházmegyei Caritastól, és ezeket a segélyeket szétosztja a rászorulóknak, a nagycsaládosoknak vagy az öregeknek vagy a betegeknek attól függ, hogy mikor milyen programot szervezett." (Sz-I-C) 
A szociális programok pénzügyi támogatásának a kérdése a legégetőbb. Két megoldás lehetséges: állandó külföldi támogatás - biztos partner - biztosítása, illetve olyan helyi gazdasági tevékenység, amelyre a szociális intézmény támaszkodhat.

„Domus. Korábban a támogatás 90-100\%-a Németországból, Angliából érkezett, még kaptunk Svájcból is, Magyarországról is pénzeket, de most a támogatások jó része pályázatok formájában érkezik. Vagyis pályázunk, onnan kapunk 15 vagy 20 ezer dollárnak vagy eurónak megfeleló lejt, természetesen a pályázat szellemében végezzük a munkát, a pályázati kiírás alapján, a kiíró követi is, hogy mit teszünk, hogyan tesszủk. Ebből a szempontból a Domus irodán nagyon-nagyon komoly és szép munka folyik, úgy erkölcsileg, mint anyagilag. A PHARE-tól kétszer nyertünk pályázatot, ezek nagyobb öszszegek voltak, jelentős segítség volt számunkra, például az elsố pályázatokból lakást is vásároltunk, bár az nem volt beleírva, a kírásban nem volt, de végül is elismerték, elfogadták. A második PHARE pályázat az új szakmák tanulása volt egy rolókat gyártó magánvállalat keretén belül, itt lehetőség nyiltt több számítógép vásárlására, számítógép kezelỏi tanfolyam múködtetésére, ezen kívül asztalosszakmát tanultak a fiatalok.”'(Sz-3-C)

„Az Omega alapítványnál hát tulajdonképpen két komoly bázisunk van, az egyik ezeken a holland barátokon keresztuil, holland alapítványok, meg az államvezetés. Az említett mezőgazdasági támogatást például a holland mezőgazdasági minisztérium biztosítja. Ugyanakkor pedig adományokból is jön természetszerüleg, ami lehet jogi vagy fizikai személy, vagy olyan nyugati ajándék, amit itt esetleg értékesítünk, és akkor az érte kapott értéket, pénzt fordítjuk karitatív célra. Tehát olyannyira nonprofit a szervezetünk, hogy senkinek semmiféle fizetése nyilvánvalóan nincs, tehát nincs alkalmazott, ezt mindenki jó szándékkal és egyénileg teszi, semmiféle nyereségünk nincs, ami pénz bejön, akármilyen ilyen-olyan ajándékokból vagy vásárlásból, azt nyilván 100\%-ban visszafordítjuk jótékony célra. Különösebben nagy pályázatunk nem volt, mert mondjam úgy, hogy helyettünk ezek a holland barátaink megoldották a kinti pályázatot, tehát tulajdonképpen az ő nevükben kint pályáztunk. Más pályázatunk, mondjuk itt romániai szinten, vagy akár magyarországi nem volt. (Sz-6-P)

„A zsoboki Bethesda sem állami, sem közegyházi évi költségvetési támogatásban nem részesül. Építkezési, felszerelési és eddigi múködési költségeit gyülekezeteink tagjainak, nőszövetségeknek, de mindenekelött külföldi test véreinknek önzetlen, az árvák iránti szeretetéből fakadó pénzbeli és természetbeni adományából fedeztük. A müködés naponkénti anyagi gondjain részben a szórványgyermekek szüleinek pénzbeli adománya is enyhít, és nem utolsó sorban az otthonnak az egyházközség földjén és az évek során vásárolt földeken kialakított kertészete és állatfarmja. A Zsobokon létrehozott és még építésben levő gazdasági egységek fokméröi a faluban végbement változásnak, gazdasági kibontakozásnak. Elsősorban ide tartozik a még 1992-ben létrehozott mezőgazdasági géppark, az 1998-ban felépített malom és pékség, a 2002-ben üzembe helyezett tehenészet, a 2004-ben felépült tejfeldolgozó, disznóhizlalda. Ezek a gazdasági egységek, melyek részben külön adminisztrációban, részben a Bethesda keretében múkődnek, és több célt szolgálnak. Elsősorban fỏleg a géppark, a malom, a pékség és a tejfeldolgozó a falut és a környéket kiszolgáló gazdasági egységek, hiányterületet fednek le. A falu és a környék ellátása mellett cél a helyi munkaerö lekơtése, a helyben maradás biztosítása. Céljuk továbbá ezeknek az egységeknek az is, hogy az otthonok tevékenységét támogassák. (K-3-C)

Rendkívüli és igen meggyőzö, ha egy oktatási intézmény támogatására létrehozott alapítvány elsö számú támogatói az intézmény tanárai. Bár az ilyen adomány öszszegszerüen nem lehet túlzottan magas, nem elégséges, de mindenképpen olyan gesztus, amire a segítségért folyamodás során hivatkozni lehet. 
„Az Orbán Balázs Alapítványnál az iskola tanügyi káderei, tehát 43-45 ember adja az anyagi alapot elsősorban. A tanïgyi káderek érdemfizetésének, tehát annak a bizonyos 15\%-nak amit kapnak, persze nem mindenki, hanem amit az alapfizetés felett kapnak, tehát gyakorlatilag a tanügyi káderek, amit a zsebükbe tehetnének, azt teszik ebbe az alapítványba. Most az utóbbi időben vannak ilyen visszajelzések, hogy a testvérvárosok iskoláitól kapunk valamennyi, hát valamennyi pénzt, bizonyos összegeket, de azt a tanügyi villa felújítására akarjuk fordítani, tehát Dunakeszitől Karcagtól, Kalocsa és Kunszentmiklóstól, a testvérvárosoktól. Aztán mi próbálkoztunk ilyen-olyan pályázatokkal, mostanában nem, viszont sajnos egyik sem jött be, nem volt sikeres, úgy hogy valahogy az embereknek a pályázástól elvette a kedvét. Pályáztunk mi annak idején az Illyés Közalapítványhoz, volt 3-4 pályázat is, de sajnos nem kaptunk semmit, úgy hogy... Hát mi mástól abszolút nem kaptunk semmit. Gyakorlatilag a tanácstól. Volt olyan eset, hogy az iskola pályázott, nem az alapítvány, kértek valamilyen összeget, valamennyit kaptak. Az idénre ígérték meg, hogy besegítenek föleg a gyermeknapi rendezvényekbe, ezt bizonyos összeggel támogatják, és lesz megyei sportverseny, hát kézilabda és futball, azt megígérték, hogy a tanács is valamennyivel segíti, de ezt még egyelöre nem kaptuk meg, valószínü, hogy csak ígéret marad, vagy nem tudom. Egy időben arról volt szó, hogy nem adhatnak, aztán most mégis úgy néz ki, hogy adhatnak, ez a jövő zenéje." (Sz-4-C)

Az önkormányzat támogatási lehetöségeivel kapcsolatos bizonytalanság áttételesen arra utal, hogy a civil szervezetek alig számolnak ezzel a forrással. Pedig lassan három éve gyakorlat, hogy iskolák, müvelödési intézmények és civil szervezetek rendezvényeit, mủvelödési programjait, kiadványait, külföldi utazásait megfelelö előírások betartása mellett önkormányzati forrásból támogatni lehet. Az illető polgármesteri hivatal, illetve megyei tanács támogatási stratégiájától függ ennek gyakorlata, illetve mértéke.

„Anyagilag is, amiben csak lehetett, támogattuk a civil szervezeteket, és meg is van, azt hiszem, a munkájuknak az eredménye. A helyi tanács anyagilag évente úgy 10-15 millió lejjel segít egy-egy szervezetet. Ebben benne van a telefonszámla, villanyszámla, de irodai bútorzatot például, most abból vett az egyik szervezet." (Gy-4-P)

„Persze, hát hogy mondjam, mi nyitottak vagyunk, tehát mi eddig még nem utasítottunk vissza egyetlen civil szervezetet sem, szervezödést sem, aki hozzánk fordult valamilyen segítségért. Világos, hogy a segítség az behatárolt, mert a mi lehetőségeink is behatároltak. Hát nem tudunk, hogy mondjam olyan arányban segíteni, ahogy esetleg elvárnák ők, de most már bevezettük azt, hogy mi is pályázati rendszeren keresztül támogassuk a jó néhány civil szervezödést, aki pályázni akar nálunk. Tavaly (2002-ben) 200 millió lejt osztottunk szét a szervezetek között, az idén felemeltük 100 millióval, tehát 300 millió lejrỏl van szó, amelyre bármely civil szervezỏdés, itt főleg müvelödési és sporthoz kötödő civil szerveződésekre gondolunk, pályázhat az önkormányzatnál. Söt meg kell hogy mondjam, a legújabb törvények alapján már csak jogi személyek pályázhatnak, tehát ma már nem jöhet egy egyszemélyes valaki, és ő kér pénzt az önkormányzattól, hogy ö valamit akar csinálni. Ezı nagyon jónak tartom, mert egy hivatalosan, jogilag bejegyzett civil szerveződés könnyebben nyomon követhető, könnyebben elszámoltatható, és valószínúleg a vezetők is nagyobb felelösséget éreznek a tevékenység iránt. Tehát egyik kapcsolatunk ez, amikor pályáztatási rendszerrel támogatjuk, a másik pedig az, hogyha hozzánk fordultak segítségért, például a bejegyeztetésnél, akkor igyekeztünk a jogi alkalmazottainkon keresztuil segíteni ezeknek az egyesületeknek vagy alapítványoknak. Ha hozzánk fordultak, akkor segítettünk mindenben, hogy mondjam, például azzal is támogathatjuk és támogatjuk is, hogy például, aki ajánlásért fordul hozzánk, az természetesen bárhova, bármikor kap ajánlólevelet, hogyha úgy látjuk, hogy a cél, az megfelel a város érdekeinek." (Sz-7-P) 


\section{Beágyazottság, kapcsolatok, együttmüködés}

A civil szervezetektől általában bizonyos művelödési szolgáltatásokat - megemlékezések, rendezvények szervezését, hagyományok ápolását, olykor hagyományteremtést - várnak el helyi szinten. Ez természetesen rendjén van, illetve volna, ha a civil szerepvállalás nem korlátozódna erre. A civil szereplés ennél több kellene, hogy legyen.

„Hogyan fogadja a Rákóczi Kultúregyletet a lakosság? Nem nagyon lehet dicsekedni. A tagsági díjakat begyüjijük, azzal nincs semmi probléma, de az nagyon kevés. Összegyülünk, elbeszélgetünk, gyüléseket tartunk, amikor szervezni akarunk valamit. Ennyi." (K-5-P)

„Az emberek többsége természetesnek tartja, hogy van a Mérai Hagyományörzök Egyesülete, de különösebben nem implikálódik. Van kb. tíz család, akikre minden téren számítani lehet, ezen kívül azoknak a gyerekeknek a szülei, akik néptáncolni járnak, szintén vállalnak feladatokat, ha szükséges. A fiatalok, gyermekek maguk is részt vesznek a munkákban: a kicsik a rendrakástól a virágültetésig, a nagyobbak pedig a javítási munkákban, ahol kell, persze változó lelkesedéssel." (K-2-C)

„Fontos rendezvényeink? A búcsú az egyik. Én vagyok a föszervezője, mint plébános és a Kolping vezetője. Komoly szervezést igényel, így közremúködik az RMDSZ, a Búzavirág, a 2-es iskola, a polgármesteri hivatal. Évente 600 ember vesz részt a rendezvényeken. Ôsszel van a Búzavirág néptánctalálkozó, ők szervezik és a kultúrház. Nem tudok pontos adatokat mondani, 250-300 érdeklődöre számíthatunk, olyankor itt van a megye minden táncegyüttese, és mások is jönnek." (P-2-C)

A nagyszabású rendezvények esetében létezik, illetve szükségképpen kialakul a partneri együttmüködés az RMDSZ, mint politikai tényező, a helyi közigazgatás és a civil szervezetek között. Különben az együttmüködésnek ez a formája annyira természetes, hogy a rá vonatkozó kérđés zavart okozó, ugyanakkor a partnerség más dimenziói fel sem merülnek, ezek szerint.

„Ünnepe különösebb nincs a Gyímeseknek, a búcsúja, ami nem kulturális. De általában úgy szokták szervezni ezt a Nemzetközi Tánctábort, hogy az befogja a Mária Magdolna búcsút is, akkor a vendégek oda is el szoktak látogatni. A Nemzetközi Tánctábor, ami évente egyszer megrendeződik, és minden második évben a Csángó Fesztivál, ez úgy van, hogy egyik évben Gyímesközéplok, másik évben Felsőlok szervezi. És mindenki részt vesz benne." (Gy-4-P)

„Vannak-e keresztúri hagyományok, amelyeket felújítottak, és ki tudta ezeket felválIalni? Nem tisztán értem, hogy milyen hagyományra gondoljak. Március 15. megszervezése volna? Hát azt az RMDSZ 1990-tôl úgymond fölvállalta, és még örökké mi csináljuk, az RMDSZ a polgármesteri hivatallal közösen. De tulajdonképpen a meghívást, az egésznek a levezénylését az RMDSZ fölvállalta, és csinálja továbbra is. Illetve július 31-ének, ugye a Petőfi emlékezésnek a megszervezését ugyancsak vállaljuk. Újabban október 23-ának a megünneplését is, illetve hát a megemlékezést az egyházakkal közösen szervezzük, ez azt jelenti, hogy van egy istentisztelet, utána pedig egy emlékezés a közösen létrehozott és megálmodott emlékoszlopnál itt a footéren, utána pedig egy gyertyás megemlékezés." (Sz-6-P) 
Az együttmüködés, a pozitív tapasztalatok dacára az önkormányzat, a helyi politikusok mintha felülröl, és nem a civil szféra iránti partneri felelösséggel kezelnék az egyes szervezeteket. Mintha a kapcsolat nem kölcsönös volna, miközben mindkét fél a közösség szolgálatában áll.

„Én nagyon örülök az egyesületeknek, akik dolgoznak és szerveznek. Mi támogatjuk őket, a helyi RMDSZ is, nagyon jó kapcsolatban vannak, és úgy érezzük, hogy a fiatalságot összefogják. Ez pedig nagyon fontos, mivel jelenleg nagyon kevés olyan rendezvény van városunkban, ami ezt meg tudja tenni. Hogyan fogadja öket a lakosság, hogyan viszonyulnak hozzájuk? El kell mondanom, hogy eleinte elég kevesen vettek részt. Ám ahogy telik az idö, egyre többen és többen vannak jelen a rendezvényeken." $(\mathrm{K}-4-\mathrm{P})$

„Van-e valamilyen együttmúködés az RMDSZ, amelynek elnöke vagyok, és az alapítványok, mondjuk éppen az Omega között? Jó kérdés. Természetesen van, mert mindenkit, az egyházakkal, a városvezetéssel, az összes karitatív szervezettel, aki néha hozzánk fordul, segítünk. Mondjak példát, mondjuk, díjazunk történelemversenyt vagy valamilyen vetélkedőt vagy sportversenyt. Aki csak hozzánk fordul azt, hogyha lehetséges, akkor támogatjuk, úgy, hogy az együttmüködés nagyon jó, úgy a városvezetéssel, mint mondom a civil szféra más képviselöivel vagy az egyházak képviselöivel." (Sz-6-P)

Ezenközben mintha a civil szervezetek sem törekednének a kiszolgáltatottságból való kitörésre. Ami különben érthetö, hiszen a semmiböl indult valamennyi, meg kellett küzdeni az elismerésen túl minden kis támogatásért, ez az alapállás viszont távlatilag nem fogadható el.

„A helyi önkormányzattal szerintem, az én meglátásom szerint, nagyon jó viszonyunk van. Ez konkrétan abban is megnyilvánult, hogy termet biztosítottak az ifjúsági szervezetnek, a teleháznak. Megszabtak egy bizonyos összeget, amit évente felhasználhatunk, amiből gazdálkodhatunk, nem túl nagy összeg, de meg van szabva, és mégis a rendelkezésünkre áll. Az iskolákkal, hát jómagam is tanító meg iskolaigazgató vagyok, úgyhogy mit mondjak... A megállói iskolával nem túl fényes a viszonyunk, de a többivel nagyon jó viszonyban vagyunk. Az egyházzal nekem ellentétes a véleményem. Én azt mondom, hogy személyfüggő az egész. Az ifjúsági szervezetböl sem mindegy, hogy odamegy valaki a kapuhoz, s valamit el akar érni, s neki azt mondja, hogy nem. Odamegyek én, s akkor azt mondja, hogy hát valahogy megcsináljuk. s akkor megcsinálja. Abszolút személyfüggö, hogy ezt most neked nem csinálom meg, neked megcsinálom." (Gy-1-C)

„A Kálmány Lajos Közmüvelödési Egyesület helyben az iskola, az egyház, az önkormányzat és az RMDSZ felé épít kapcsolatokat. Mindegyikkel jó viszonyt ápol. Arad közelsége, és az a tény, hogy a tagság egy része Aradon él, lehetôvé teszi, hogy közremúködjön a megyeközpont kulturális életének szervezésében is. Ezen kívül külföldi kapcsolatokkal is rendelkezik." (P-3-C)

,Az egyesületünknek fontos volt, hogy mi is, $s$ az egyesület is beilleszkedjen a társadalomba, föleg Keresztúr társadalmába, ezért igyekeztünk kapcsolatokat teremteni egyházakkal, más szervezetekkel, és mindenkivel sikerült eredményes együttmüködést folytatni. A polgármesteri hivatal egyik fö támogatónk volt, bár erkölcsileg föleg, de az anyagi támogatást sem lehet elhanyagolni, mivel ök biztosítanak irodahelységet az egyesületünk számára 25 évig bérmentve. Amikor ezt a termet megkaptuk, akkor az egy nagy-nagy ajándék volt számunkra, mert az egyesületünknek alig volt pénze a fiatalok támogatására, nem hogy bért tudjon fizetni." (Sz-3-C) 
A civil szervezetek igazi erőt akkor képviselnek, ha megfelelő együittmúködés létezik egyrészt az egyes szervezetek között, másrészt részt vesznek a helyi világ történéseiben, véleményt nyilvánítanak fontos és a lakosság jelentős részét érintő kérdésekben - oktatási intézmények múködése, kultúra, környezetvédelem, szociális helyzet -, olykor pedig éppen egy civil szervezet tematizál a helyi közvélemény számára fontos ügyet vagy folyamatot. Az infrastrukturális fejlesztések, a szociálpolitika helyi hatásai számtalan lehetöséget kínálnak erre. Ehelyett beszorulnak egyesületi ügyeik keretei közé. Illetve, ha általános témát érintenek, nem tisztázzák, kinél látják a felelösséget.

„Van elég szervezet, ha mindegyik jól elvégezné a munkáját, akkor nem lenne ok panaszra. A fiatalokkal azonban többet és jobban kéne foglalkozni, de ezt szervezzék meg maguknak. Sajnos nincs igényük a közösségi életre, inkább nézik a TV-t, vagy mennek a diszkóba. Itt nálunk, a Kolpingban lehet ping-pongozni, szórakozni, de csak a tizenévesek jönnek, ahogy idösebbek lesznek, elmaradnak, és inkább mennek a kocsmába, diszkóba." (P-2-C)

„Lehet, hogy máris túl sok szervezet müködik. Nem vagyunk olyan sokan, hogy megengedhessük magunknak, hogy elfecséreljük az energiáinkat. A fiatalokkal nem csak kulturális értelemben, hanem szakmai értelemben is foglalkozni kell. Ha nincs lehetőségük arra, hogy jó munkahelyük legyen, házat vegyenek, családot alapítsanak, nem várhatjuk el, hogy Pécskán maradjanak. Ennek biztositása kéne, legyen a legfontosabb cél." (P-4-C)

Van arra példa, hogy érzékelik a közös fellépés, egyfajta koordináció szükségességét. De ilyen esetben sem lépnek túl a láthatatlan civil korláton, nem jutnak el a közösségi civil kontroll gondolatáig, annak felismeréséig, hogy a szolgáltatásaik okán legitim módon nyilatkozhatnának meg a helyi közösség legfontosabb kérdéseit illetöen.

„Legfontosabb, ami kellene, legyen egy egyesület, ami a gyímesi régiót összefogná, egy egyesületet létrehozni, ami nemesak kimondottan kultúrával vagy teleházzal foglalkozzon, hanem ami gyímesi csángókat összetartja, viszont ehhez én még kicsike vagyok. Mondjak példát, pl. Tankó Gyula, Berszán Lajos, elég nagy neveket monđok nem? Ök kellene, hogy ilyesmit csináljanak, viđékfejlesztést, az emberekben felébreszteni a tudásvágyat." (Gy-2-C)

„Akárcsak máshol, Pécskán is olyan szervezetre lenne szükség, amely képes átfogni a létezőket, képes összehangolni müködésüket. A már meglévök között erre a szerepre nincs potenciális jelölt. A rendezvények kapcsán: a már említett magyar falunap lenne nagyon fontos." (P-3-C)

„Talán azt mondhatnánk, mindenki végzi a saját magára vállalt feladatát, nem nagyon látok ilyen összehangolt segítséget. Szerintem nem is tehetne, annyira különbözö szegmentumait ölelik fel a tevékenységek a társadalomnak. Nem látom azt, hogy össze lehetne öket hangolni, tehát erre azért próbálkozás volt olyan értelemben, ahogy a helyi tanácsnak a szociális bizottsága, az próbált. Annak én is tagja vagyok. S akkor ezek, többnyire ezeknek a civil szervezeteknek a tagjai ott is együtt vagyunk, s akkor ilyen értelemben, hogyha valahol olyan gond merül fel, akkor közösen is fel tudunk lépni. Hát erre mondjuk volt példa, de így rendszeresen, intézményesítve együttmüködés, hogy legyen a civil szervezeteknek, monđjuk egy csúcstalálkozója, ahol megbeszélnénk, mondjuk Keresztúri problémákat, megbeszélnének vagy közösen lépnének fel, ilyenröl nem tudok." (Sz-5-V) 
Az önkormányzatok minden további nélkül támaszkodhatnának a civil szervezetek szakmaiságára és terepismeretére, a tanácsi szakbizottságok mellé civil konzultatív csoportokat szervezhetnének. Erre a vizsgált térségben, az egyetlen fenti utaláson kívül, semmilyen jel nem utal.

A közéletet tematizáló, értékelö magatartás, a megszokottól eltérő szerepvállalás viszont igen sok szervezet esetében önnön státusának és helyzetének a felülvizsgálatát jelenti, illetve jelentené, amennyiben vállalkoznának vezetöi erre. Hiszen még mindig megmutatkozik annak a kilencvenes évek elején kormányszintröl is sokszor visszaigazolt szemléletnek a hatása, miszerint a civil szféra szereplöi ügyeskedök, akik személyes vagy kiscsoportos anyagi haszon reményében vállalják és végzik tevékenységüket. A román(iai) közgondolkodásban még nem vált ismert és vállalt alapigazsággá azon, a nyugati demokráciákban a feladatmegosztást meghatározó tétel, hogy a politikai szféra legfontosabb partnere éppen a civil, még akkor is, ha olykor kontroll szerepre vállalkozik. Annak a devolúciónak, amely nélkül modern demokráciáról ma már nem lehet beszélni, az egyik lehetséges útja éppen bizonyos közösségi feladatok kihelyezése - természetesen a megfelelö pénzügyi források biztosításával - a civil világba, ami a köztehervállalás terén jelenti a partnerséget. Ha általános kérdésröl szól egy civil vezető, úgy teszi, mintha saját magára és társaira vonatkoztatná mondandóját.

„Valamikor 9000 lélekszámú magyar közösség volt Pécskán, akkor össze tudták fogni a közösséget. A háborúk, a kommunizmus megtanította az embereket arra, hogy ne foglalkozzanak a közösséggel. Nem igaz, hogy Pécskán nincs pénz a kultúrára, a pécskaiak mindig is nagyon gazdagok voltak, csak most nem mérik fel ésszel, hogy mire kéne költeni." (P-2-C)

„Együttmüködés? Semmi. Itt gyakorlatilag mindenki süti a saját sütnivalóját. Hát például az Orbán Balázs Alapítvány most már anyagilag olyan erös alapokon áll, hogy mi, a Petöfi Sándor Alapítvány melléjük nem tehetjük magunkat. Hát nekünk kevés, kicsi összeg az a 15\%, a támogatás. De nem mindenkinek jár a $15 \%$, hanem az meg van határozva, nem tudom, 8-10-en kapják azt a 15\%-ot, mások kevesebbet, vagy semmit." (Sz-4-C)

Különbség mutatkozik a civil szféra szerepvállalásának megítélésében az etnikai törésvonalon: a román polgármester sokkal jobb véleménnyel van a magyar, mint a román szervezetek tevékenységérỏl. $S$ a román közeg nyílván kondicionálja a magyar szervezetek megnyilvánulásait is.

„A magyar vonatkozásokról azt tudom mondani, hogy sokkal előbbre járnak, mint a román kezdeményezések, nem hiszem, hogy nincs lefedve a közösségi élet minden szintje, inkább ők is a szociális oldalon akarnak erösíteni. Mindenesetre a magyarok sokkal kezdeményezöbbek, mint a románok. Talán azért is, mert olyan igényeik vannak. melyeket az állami intézmények nem tudnak felvállalni. Román részröl nem dívik az öntevékeny szerveződés, inkább mindent az önkormányzattól várnak. A román és magyar szervezetek között nincs hivatalos együttmüködés, inkább csak a személyes ismeretségeken áll vagy bukik az együttmüködés. A magyar szervezetek köztudottan jói dolgoznak együtt, összetartanak, segítik egymást. A román szervezetek között is létezik kooperáció és némi nemü átfedés is, hiszen Pécska viszonylag kis település, természetes, hogy aki tenni akar valamit, az mindenütt jelen van." (P-5-P) 
A helyi politika első emberei is szolgáltatásközpontú szemléletủek, a civil szféra szerepe helyett feladatokban gondolkoznak. A civil szféra-önkormányzat kapcsolat elvi kérdéseire nem térnek ki, talán nem is foglalkoztatja öket a kérdés. Persze, ezenközben nem szabad elfelejteni, hogy kezdeményeznie a civil szférának kellene.

„A szociális és ifjúsági szféra teljességgel lefedetlen. Az öregek otthonán kívül szükség lenne egy kantinra is. A mozgássérülteket, minimálbér alatti jövedelemböl tengödőket fel kéne karolni. A határ közelségét is jobban ki kéne tudni használni." (P-5-P)

„A civil szféra itt még gyerekcipöben jár. Ez így van sajnos. Van, amit nagyon hiányolok, a vállalkozók és a polgármesteri hivatal közötti kapcsolat, ami sajnos hiányos, ezeket összehozni egy hivatallal vagy egy ilyen ifjúsági szervezettel, de úgy néz ki, nem érdekeltek. Voltak olyan esetek, hogy pénzhiányból elindultak pénzt gyüjteni, az ifjúsági szervezet, egy gyermeknap megszervezésére, $s$ általában a kisebb vállalkozók szívesen fogadıák, és anyagilag lámogatták, de a nagyobbak nem, nincsen rá idő." (Gy-4-P)

„A szociális jellegŭ szervezetek vagy például az iskola mellett müködő alapítványok együttmüködése milyen? Hát én úgy látom, hogy inkább egyelöre még mindenki igyekszik a saját maga dolgát rendezni. Ez abból fakad inkább, hogy szükösek a források, tehát a pályázatok általában célpályázatok, és mindenki igyekszik kikeresni azt, ami pontosan rá talál. Ugye az iskola mellett müködő alapítvány az oktatás minöségének a javítását tüzte ki célul, nem különösképpen megy el a szociális témák felé. Különösképpen nem megy el, hogyha nincs olyan vegyes pályázat, mondom én. Különben persze, hogy van együttmüködés, hiszen például, amit az egyik iskolának, alapítványnak sikerül megszerezni, és mondjuk, sikerül többet szerezzen abból a dologból, vagy esetleg neki már van olyan, akkor volt példa rá, hogy átadta a másik iskolának. Ez akkor segítség, hát például a fiatfalvi iskolát segítik a Petötitő̉l és az Orbán Balázs Alapítványtól, ugye az egy szegényebb iskola, mindenféle szempontból hátrányosabb helyzetben van. Tudok konkrét esetet, amikor fénymásolóval vagy számítógéppel, olyasmivel, amire éppen nekik lehetöségük, de segítették, az biztos." (Sz-7-P)

\section{Következtetések}

Az interjúk alapján kialakuló kép mind általánosan, mind a részleteket illetően pozitív. A civil szereplőkre jellemző a közösségi felelösségvállalás és elkötelezettség. Általánosnak mondható a humán és anyagi eröforrások szükössége. Ugyanakkor bizonyos tényezők, illetve körülmények okán a jelenlegi helyzet önmagát újratermelö, ez a helyzet nem teszi lehetővé a civil szféra szerepének és felelősségének a kor követelményeinek megfelelö újrafogalmazását, ennek érdekében ki kellene törni a jelenlegi társadalmi-mentális keretböl.

- Ismertség. A civil szervezetek tevékenysége ismert és elismert. Miközben helyi szinten a szereplök jónak és szükségesnek tartják múködésüket, a központi megítélés mintha továbbra is egy korábbi, tízegynéhány éves téveszme hatása alatt volna, miszerint a civil világ ügyeskedőkböl áll, akik személyes érdekből hozták létre szervezetüket. Ez mindenekelött a finanszírozási politikában nyilvánul meg, $s$ ameddig a támogatások kezelöi nem partnerként tekintenek e szervezetekre, megmarad a civil szervezetek kiszolgáltatottsága. 
- Támogatások. A civil szervezetek támogatását illetően paradoxon figyelhető meg: miközben ezen szervezetek közfeladatokat vállalnák át, vagyis valamilyen közintézmény feladataiból vállalnak át jelentős terheket, a legkisebb anyagi támogatást éppen költségvetési forrásokból kapják. Már ma érzékelhetö, hogy a külföldi támogatások területén váltás érlelödik: új programot alig vállalnak, a korábbiak esetében is elvárják az alternatív források létét. Talán fölösleges hangsúlyozni, hogy a külföldi támogató jogos elvárása lehet, hogy például szociális rendszerek múködtetésében fele-fele alapon vegyenek részt az illetékes közintézmények.

- Müködési biztonság. Igazi biztonság csak azon szervezetek esetében létezik, amelyek saját anyagi forrással rendelkeznek, vagyis valamilyen gazdasági tevékenységból biztosítják a vállalt program finanszírozását. A pénzszủke általánosnak mondható, és mivel a pályázati úton szerezhető pénzek programokra fordíthatók csak, a szociális szolgáltatást biztosító szervezetek kivételével nincs saját alkalmazott, ügyvivő, aki a müködés folyamatosságának és megfelelő színvonalának volna/lehetne első számú biztosítéka.

- Tevékenységi területek. A müvelödés túlsúlya a vállalt feladatokat illetỏen várható és érthető. Sok esetben hivatásos intézmény tevékenységét kell pótolni, feladatait átvállalni. Viszont sok esetben nincsenek iskolákat, az oktatási folyamatot támogató szervezetek, pedig ezek szükségessége, illetve pozitív hatása vitathatatlan. Úgy tünik, az erős iskola, illetve az erös helyi kisebbségi közösség a civil szervezet megalakulását hajlamosító tényezök. Továbbá teljesen hiányoznak a szórakozásra-sportra szakosodott szervezetek, erötlenek - ha vannak - a gazdaságiak, nem jöttek létre a település fejlesztését szolgáló szervezetek. A környezetvédelem is éppen hogy jelen van, pedig tennivaló volna rengeteg.

- Beágyazottság. A civil szervezetek többnyire beszorulnak egyesületi ügyeik keretei közé. Alig van arra példa, hogy ne egy-egy rendezvény vagy közösségi feladat, hanem a helyi társadalom helyzetének elemzése hozná össze öket. A politika sikerrel tartja meg a civil szervezeteket a társadalom kisasztalánál, nem sok jel mutat arra, hogy volna hajlandóság a mai helyzet feloldására. A közösségi felelösségvállalás éthosza és a civilek szakmai felkészül tsége olyan tényezök, minek okán helyet kellene kapniuk a helyi döntéselőkészítésben, a közösségre vonatkozó napi és távlati programok kidolgozásában. A civil szervezetek társadalmi kontroll szerepe sem érvényesül a legtöbb esetben.

- Etnikai különbség. Általánosan nem bizonyított tétel, de léteznek olyan jelzések, miszerint a helyi közösség szolgálatában a kisebbségi - magyar - civil szervezetek többet teljesítenek a többségi - román - szervezeteknél, a románság inkább hagyatkozik igényeinek teljesítését illetően az államra, a helyi közigazgatásra. 


\section{Jegyzetek}

${ }^{1}$ A térelemekkel, térszerkezettel kapcsolatos elméleti bizonytalanságokra többen figyelmeztetnek, még arról is vannak viták, hogy a komplex régiókutatás mennyire ónálló tudományterület (Nemes Nagy 2003).

2 2000-tôl világosan érzékelhető a civil szféra társadalmi jelenléte, amikor már nem fogadja el a kilencvenes évek elejére, közepére jellemző gyakorlatot, a megtürtség állapotát, és egyértelmú jelzések mutatják, hogy új helyzet van, amikor a civil szereplö minden társadalmi folyamatban igényli, hogy a politika intézményei társként kezelje öket.

${ }^{3} \mathrm{Az}$ itt felsorolt szervezet-kategóriák az ERMACISZA által használt besorolást követik.

${ }^{4}$ Nem foglalkoznak helyi erőforrások feltárásával, igények és szükségletek értelmezésével, közintézmények mủködésének elemzésével - olyan kérdésekkel, amelyek bármilyen jövö́t illetỏ stratégia alapelemei.

${ }^{5}$ Az interjúkat készítették: Sárig Anna (Gyímes), Szöcs Edit (Székelykeresztúr), Török Tímea (Kalotaszeg) és Bognár Levente (Pécska). Az interjúkkal kapcsolatos észrevételeik fontosak voltak a következtetések megfogalmazásakor. Köszönet érte. És köszönet Nagy István pécskai alpolgármesternek a kutatás során nyújtott támogatásért.

${ }^{6}$ A pontos adatot nem sikerült megtudni. A statisztikai hivataltól elirányítottak, a statisztikai évkönyv ilyen adatot nem tartalmaz. Az országos civil ernyöszervezet, a FDSC honlapján a civil szféra bemutatásakor számolnak 25 ezer szervezettel. (http://www.fdsc.ro, 2004. október 1.)

A temesvári AIDONG adatbázisa tartalmazza ezek adatait, Nicoleta Stoica közlése (2004. okt. 2.).

${ }^{8}$ A temesvári Szórvány Alapítvány adatai szerinı 49-röl 53-ră növekedetı a megyében a magyar civil szervezetek száma.

${ }^{9}$ Pécskáról nem kértünk adatokat, mivel egyértelmủek és egybehangzóak voltak a megkérdezettek válaszai.

${ }^{10}$ A kalotaszegi adataink a zsoboki Gyermekotthont és Idỏsek otthonát tartalmazzák pluszban.

${ }^{11}$ Az ERMACISZA listája tartalmaz még négy önkormányzati intézményt (iskola, óvoda, múzeum) és három egyházat. Utóbbiak valóban a civil társadalom részei, de nem tekinthetök olyan civil szervezödéseknek, mint egy alapítvány vagy egyesúlet. Az önkormányzati intézmények nem önmagukban, hanem akkor jöhetnek számításba, ha valamilyen szervezet létezik mellettủk pótlólagos támogatások szerzése érdekében.

${ }^{12}$ A 2002-es népszámlálás szerint Pécska lakossága 11 435, a hozzá tartozó falvaké (Tornya, Szederhát, Bodrog) összesen 1570 fó.

${ }^{13}$ A helyi véleményvezér megtalálása valamivel bonyolultabb feladat, mint a többi vezetöé. Terepismeret hiányában kísérletezni kell, s ez a lekérdezést végzỏ diákok esetében - idöhiåny miatt - elmaradt.

${ }^{14}$ A kis esetszám miatt igazi rangsor 3 esetben igazából nem állitható fel, de Székelykeresztúr adatai egyértelmüen jelzik, hogy a civil szféra szereplöi ritkán, vagy nem érzik szükségesnek a mozgalom egészéröl tájékozódni. A szórvány (Pécska) és az erős kisebbségi helyzet (Kalotaszeg) változtat ezen a helyzeten annyiban, hogy itt nagyobb az igény egymás erkollcsi-szervezeti támogatására, tehát jobban ismerik egymást a szervezetek vezetói.

15 Minden kód egy betüböl, egy számból és egy újabb betüböl áll. Az első betủ jelentése: Gy Gyímesek, Sz - Székelykeresztúr, K - Kalotaszeg, P - Pécska. A szám jelentése: az interjú sorszáma. A második betú: $\mathrm{C}$ - civil, E - egyházi, V - véleményvezér, $\mathrm{P}$ - politikus.

\section{Irodalom}

Arató A. (1999) Civil társadalom, forradalom és alkotmány. Új Mandátum, Budapest.

Chatterjee, P. (2001) On civil and political society in post-colonial democracies. - Kapiraj, S.-Khilnani, S. (eds.) Civil Society. History and Possibilities. Cumbridge University Press, Cambridge.

Nemes Nagy J. (2003). A regionális tudomány dualitása és paradigmái. - Tér és Társadalom. 1. 1-17. 0. Papp Z.A. (2001) Sétanyomatok. Pro-Print, Csíkszereda.

Seligman, A.B. (1997) A civil târsadalont eszmeéje. Kávé Kiadó, Budapest.

Szabó M. (1999) Globalizáció, civil társadalom és jogvédelem. - Csefkó F.- Horváth Cs. (szerk.) Magyar és európai civil társadalom. MTA RKK. Pécs. 26-45. o.

Túros E. (szerk.) (1995) Változásban? Elemzések a romániai magyar társadalomról. KAM, Csíkszereda. 